\title{
MITOCHONDRIAL DNA ANALYSES AND THE ORIGIN AND RELATIVE AGE OF PARTHENOGENETIC CNEMIDOPHORUS: PHYLOGENETIC CONSTRAINTS ON HYBRID ORIGINS
}

\author{
C. MORITZ, ${ }^{1,3}$ J. W. WRIGHT, ${ }^{2}$ AND W. M. BROWN ${ }^{1}$ \\ 'Laboratory of Molecular systematics, Museum of Zoology and Department of Biology, \\ University of Michigan, Ann Arbor, MI 48109 USA \\ ${ }^{2}$ Section of Herpetology, Natural History Museum of Los Angeles County, \\ Los Angeles, CA 90007 USA
}

\begin{abstract}
Within the genus Cnemidophorus, parthenogenesis has arisen by hybridization several times. This provides the opportunity to investigate general features of hybridization events that result in the formation of parthenogenetic lineages. The relationships of mtDNA from all bisexual species of Cnemidophorus known to be parents of parthenogens were investigated to evaluate phylogenetic constraints on the hybrid-origin of parthenogenesis. No phylogenetic clustering of the parental species, either maternal or paternal, was apparent. However, the combination of bisexual species that have resulted in parthenogenetic lineages are generally distantly related or genetically divergent. This contrasts with the expectation if parthenogenesis in hybrids is due to the action of a single rare allele, but is consistent with the hypothesis that some minimal level of divergence is necessary to stimulate parthenogenetic reproduction in hybrids.
\end{abstract}

Key words. - Cnemidophorus, evolution, hybridization, lizards, mtDNA, parthenogenesis, phylogeny.

Received December 14, 1989. Accepted June 28, 1991.

The rarity of alternatives to bisexual reproduction has stimulated a plethora of theories about the evolutionary advantages of sex (reviewed by Bell, 1982; Michod and Levin, 1988). Some suggest that bisexual reproduction is predominant because it generates ecologically diverse offspring, others that it confers greater resistance to parasites, and others that it allows the repair of damage to DNA and prevents the accumulation of deleterious mutations. A common feature of these models is that parthenogenesis is supposed to result from a simple genetic mutation, usually at a single locus.

The transition from bisexual to parthenogenetic reproduction requires the origin of mechanisms to consistently produce a high proportion of unreduced gametes (reviewed by Suomalainen et al., 1987), and to initiate development in the absence of fertilization. White (1978 p. 294) likened these events to a "cytological tour de force" or a "macromutation." In fact, the transition to parthenogenesis is frequently imperfect, resulting in reduced fecundity or offspring viability (Lamb and Willey, 1979;

\footnotetext{
${ }^{3}$ Present address: Department of Zoology, University of Queensland, QLD 4072 AUSTRALIA.
}

Wetherington et al., 1987). It may be that the predominance of bisexual reproduction is partly due to the difficulty of evolving alternatives (Williams, 1975; White, 1978; Templeton, 1982; Vrijenhoek, 1989; Moritz et al., 1989a).

For this reason, it is important to understand how parthenogenetic lineages arise. Do extant lineages provide evidence for constraints on their origin? What is the genetic basis of parthenogenesis? Unfortunately, because of inherent difficulties in employing segregation analysis for parthenogenetic lineages, direct evidence on the genetic basis of this syndrome is scant. Models based on single genes may be appropriate for some groups where parthenogenesis has arisen spontaneously within a bisexual population (White, 1978; Templeton, 1982). Single gene mutations resulting in the loss of meiosis (apomixis) have been reported in Maize (Golubovskaya, 1979) and apomixis in Daphnia may also be due to a single gene (Innes and Hebert, 1988). However, the genetic basis of hybrid parthenogenesis may be more complex. Here, the production of unreduced gametes may depend on interactions among divergent alleles at many loci, rather than at a 
single locus (White, 1978; Moritz et al., 1989a).

Genera within which many parthenogenetic lineages have arisen many times provide an excellent opportunity to investigate how this event occurs. Approximately one-third of the species within the genus Cnemidophorus (whiptail lizards), are parthenogenetic and all have arisen through hybridization between bisexual species (Wright, 1978; Dessauer and Cole, 1989; Sites et al., 1990). Previous studies of mtDNA in the parthenogens and their bisexual relatives (Brown and Wright, 1979; Wright et al., 1983; Densmore et al., 1989a, $1989 b$; Moritz et al., 1989b; Vyas et al., 1990) have identified the species or subspecies that provided the maternal parent(s) of the initial hybrids, in some cases providing strong evidence for hybrid origins.

Another feature of these studies is that, without exception, the parthenogens had very low mtDNA sequence diversity, both in absolute terms and relative to the bisexual ancestors. This observation suggests that each of the extant parthenogenetic lineages arose recently from one to a few closely related females (Densmore et al., 1989a; Moritz et al., 1989a; Vyas et al., 1990).

In this paper, we use the distribution of mtDNA cleavage sites to investigate the phylogenetic relationships between the bisexual species of Cnemidophorus that have hybridized to produce parthenogenetic lineages. Based on the assumptions that hybrid parthenogenesis could be due to one or a few genetic factors and that such factors arise infrequently, Darevsky et al. (1985) argued that alleles for parthenogenesis should be phylogenetically restricted. Thus, in a genus such as Cnemidophorus there should be "two independent lineages, one of which has evolved a genetic factor or factors that determine clonal reproduction in hybrids" (Darevsky et al., 1985 p. 495).

By contrast, Moritz et al. (1989a) suggested that hybrid parthenogenesis stems from a more generalized genetic interaction leading to the production of unreduced gametes yet not reducing offspring viability. According to this "balance" hypothesis, it is the amount of divergence across many genes that is critical, not the presence of a specific allele at one locus. This predicts that there should be a threshold of divergence between bisexual species below which hybrids do not reproduce parthenogenetically, but does not require phylogenetic clustering of the parent species.

\section{Materials AND MethodS}

Mitochondrial DNAs were prepared and assayed with restriction endonucleases as described previously (Brown, 1980; Wright et al., 1983; Densmore et al., 1985). Cleavage maps were constructed for each species using the double digestion method (Dowling et al., 1990) and aligned based on the position of several highly conserved sites (e.g., Moritz and Brown, 1987). Alignments and the location of selected informative cleavage sites were tested in critical side-byside double digestion experiments. The orientation of cleavage maps with respect to the gene order is known from electron microscopy of expanding mtDNAs with expanding D-loops (Brown and Wright, 1979).

Sequence divergence between mtDNAs was estimated from the proportion of shared cleavage sites according to the equations of Nei and Tajima (1983). These values were used to cluster mtDNAs using the UPGMA algorithm implemented in a basic program described by Nei et al. (1985). Relationships among mtDNAs were investigated by treating cleavage sites as characters (binary states: presence/absence) and searching for the most parsimonious solution(s) using PAUP version 3.0 (Swofford, 1990).

\section{RESULTS}

The parent species for each of the parthenogenetic lineages of Cnemidophorus are listed in Table 1. By combining all the available genetic evidence, we can identify a minimum of nine primary hybridization events forming allodiploid parthenogens, in addition to subsequent hybridizations to form allotriploid lineages. As discussed previously (Lowe et al., 1970) the bisexual parents are distributed among several different species groups; the South American lemniscatus group, the central American deppei group, and the North American sexlineatus and tigris species groups. Parthenogenesis has arisen through hybridization between species of the same group, e.g., C. lemniscatus, $C$. uniparens, or between members of 
TABLE 1. Bisexual species involved in the hybrid origins of parthenogenetic lineages of Cnemidophorus. Estimates of sequence divergence between mtDNAs (see Table 2 and, for C. lemniscatus, Vyas et al., 1990) and genetic distances ( $D_{\text {NEI }}$, Nei, 1972) based on allozyme electrophoresis (Dessauer and Cole, 1989; Sites et al., 1990) are given for the bisexual species involved in the formation of allodiploids. In some cases, these allodiploids subsequently hybridized with males to produce allotriploid lineages. The parentage is based on the previous studies of chromosomes and proteins (reviewed by Wright, 1978; Dessauer and Cole, 1989) and mitochondrial DNA (references above). C. tesselatus is thought to have arisen at least twice (Densmore et al., 1989b).

\begin{tabular}{|c|c|c|c|c|}
\hline Maternal parent & Paternal parent & Parthenogens & mtDNA & $D_{\text {NEI }}$ \\
\hline \multicolumn{5}{|c|}{ Inter species-group hybridizations: } \\
\hline angusticeps & deppei & cozumela group & $15 \%$ & - \\
\hline motaguae & guttatus & sp. $G^{1}$ & $15 \%$ & - \\
\hline marmoratus & inornatus & neomexicanus & $12 \%$ & 0.31 \\
\hline marmoratus & septemvittatus & tesselatus & $8.7 \%$ & 0.31 \\
\hline \multicolumn{5}{|c|}{ Intra species-group hybridizations: } \\
\hline lemniscatus $\mathrm{D}$ & lemniscatus $\mathrm{E}$ & lemniscatus A-C & $12 \%$ & 0.21 \\
\hline gularis & sexlineatus & laredoensis & $5.1 \%$ & 0.19 \\
\hline costatus $^{3}$ & inornatus & velox, exsanguis & $7.7 \%$ & 0.20 \\
\hline inornatus & costatus & nine $\operatorname{tax} a^{2}$ & $7.7 \%$ & 0.20 \\
\hline
\end{tabular}

1 sp. $\mathrm{G}$ is an undescribed allodiploid species (Wright, unpubl. data).

2 This group includes nine morphologically distinct lineages, eight of which are triploid (Densmore et al., 1989b)

3 It remains possible that the maternal parent of these species was from the closely related C. burti stictogrammus (Moritz et al., 1989b).

different groups, e.g., C. tesselatus, $C$. neomexicanus, and C. cozumela.

Detailed cleavage maps are available for mtDNAs from C. tigris marmoratus (Densmore et al., 1985), C. lemniscatus (Vyas et al., 1990), C. costatus, C. burti, C. septemvittatus septemvittatus, $C$. septemvittatus scalaris (Moritz et al., 1989b), C. inornatus and $C$. sexlineatus (Densmore et al., 1989a). Less detailed cleavage maps of $C$. gularis were included in Wright et al. (1983) and Moritz and Brown (1987). In the present study these maps were extended to cover the 5 and $6 \mathrm{bp}$ sites for the all restriction endonucleases listed in Table 3. Cleavage maps have also been prepared for C. motaguae, $C$. angusticeps, $C$. deppei, and $C$. guttatus (C.M., V. Singh, J.W.W. and W.M.B., in prep.). Thus, mtDNA cleavage maps have been constructed for all of the bisexual species thought to be involved in the origin of parthenogenetic Cnemidophorus. The following analyses are restricted to one cleavage type from each bisexual species, selected on the basis of maximum genetic similarity to the parthenogens (cf Densmore et al., 1989a, 1989b; Moritz et al., 1989b).

Comparison of these cleavage maps revealed levels of sequence difference ranging from 2.6 to $21 \%$ (Table 2). Of the mtDNAs compared, those of the lemniscatus group (D and $\mathrm{E}$ chromosome races of $C$. lemniscatus) were particularly distinct, with differences between these and other $\mathrm{mt}$ DNAs ranging from 14 to $21 \%$. The next most distinctive mtDNAs came from the deppei group, represented by $C$. deppei and C. guttatus. The species from these two groups are clearly separated from the others (representing the sexlineatus and tigris species groups) in the UPGMA clustering analysis (Fig. 1). mtDNA divergences between the parent species ranged from 5.1 to $15 \%$ (Table 1).

For the phylogenetic analysis, sites cleaved by $N c i$ I were also included for $C$. s. septemvittatus, C. s. scalaris, C. gularis, C. costatus, $C$. inornatus, and C. t. marmoratus. These characters were coded as having unknown states in the remaining taxa. A total of 152 distinct sites were mapped among the 13 mtDNAs, with between 32 and 42 sites (excluding $N c i$ I) mapped per genome (Table 2). Of the 152 sites, 83 had unique (autapomorphic) states or were invariant and 71 were phylogenetically informative (Table 3). mtDNAs from $C$. lemniscatus were selected as outgroups because they were the most distinct molecularly and geographically, and because Burt (1931) argued that these South American lizards had many primitive morphological features relative to the North American species. 
TABLE 2. Estimates of percent sequence divergence among mtDNAs from bisexual species of Cnemidophorus involved in the hybrid origins of parthenogenetic lineages. Estimates are below the diagonal, their standard deviations are below, and the number of mapped cleavage sites is on the diagonal. Abbreviations: LEM $=C$. lemniscatus (chromosome forms D and E), DEP $=C$. deppei, GUT $=C$. guttatus, $\mathrm{ANG}=C$. angusticeps, MOT $=C$. motaguae, $\mathrm{GUL}=C$. gularis, $\mathrm{SEP}=C$. s. septemvittatus, $\mathrm{SCA}=C$. s. scalaris, $\mathrm{COS}=C$. costatus, $\mathrm{INO}$ $=C$. inornatus, $\mathrm{SEX}=C$. sexlineatus, $\mathrm{MAR}=C$. marmoratus.

\begin{tabular}{|c|c|c|c|c|c|c|c|c|c|c|c|c|c|}
\hline \multirow[b]{2}{*}{ Group } & \multicolumn{2}{|c|}{ lemniscatus } & \multicolumn{2}{|l|}{ deppei } & \multicolumn{8}{|c|}{ sexlineatus } & \multirow{2}{*}{$\begin{array}{c}\text { tigris } \\
\text { MAR }\end{array}$} \\
\hline & LEMD & LEME & DEP & GUT & ANG & MOT & GUL & SEP & SCA & $\cos$ & INO & SEX & \\
\hline LEM D & 37 & 2.5 & 3.3 & 3.1 & 3.3 & 3.3 & 4.1 & 4.0 & 3.4 & 3.6 & 3.4 & 3.1 & 2.8 \\
\hline LEM E & 12 & 33 & 3.2 & 3.2 & 2.9 & 3.5 & 3.7 & 3.2 & 2.9 & 3.2 & 3.8 & 3.5 & 3.6 \\
\hline DEP & 17 & 16 & 35 & 1.1 & 2.9 & 3.1 & 3.0 & 2.8 & 2.8 & 2.7 & 3.1 & 3.0 & 3.2 \\
\hline GUT & 16 & 16 & 4.0 & 36 & 2.8 & 2.9 & 2.9 & 2.9 & 2.5 & 2.3 & 2.9 & 2.7 & 3.0 \\
\hline ANG & 18 & 14 & 15 & 14 & 38 & 0.9 & 1.5 & 1.3 & 1.4 & 1.5 & 1.7 & 1.5 & 1.8 \\
\hline MOT & 17 & 18 & 16 & 15 & 2.6 & 37 & 1.8 & 1.5 & 1.7 & 1.3 & 2.0 & 2.0 & 2.2 \\
\hline GUL & 21 & 18 & 15 & 14 & 6.5 & 7.7 & 33 & 1.1 & 1.1 & 1.4 & 1.9 & 1.4 & 2.1 \\
\hline SEP & 21 & 16 & 15 & 13 & 5.4 & 6.3 & 4.3 & 42 & 1.0 & 1.1 & 1.9 & 1.4 & 1.8 \\
\hline SCA & 18 & 15 & 14 & 12 & 5.9 & 7.7 & 4.2 & 3.9 & 39 & 1.3 & 1.9 & 1.5 & 1.9 \\
\hline $\mathrm{COS}$ & 18 & 16 & 13 & 11 & 5.8 & 5.0 & 5.3 & 4.3 & 4.8 & 33 & 1.8 & 1.5 & 2.0 \\
\hline INO & 19 & 19 & 16 & 15 & 7.4 & 9.4 & 8.5 & 9.0 & 9.1 & 7.7 & 37 & 1.3 & 2.5 \\
\hline SEX & 17 & 17 & 15 & 13 & 6.3 & 9.1 & 5.1 & 5.9 & 5.8 & 5.8 & 4.7 & 32 & 2.1 \\
\hline MAR & 18 & 18 & 16 & 15 & 8.6 & 11 & 9.8 & 8.7 & 8.8 & 9.0 & 12 & 9.6 & 39 \\
\hline
\end{tabular}

Analysis of all possible trees (PAUP; branch and bound option) revealed a single shortest tree of 136 steps, a consistency index of 0.52 and a retention index of 0.59 . This tree has the same topology as the UPGMA dendrogram except that $C$. gularis was more closely related to $C$. $s$. scalaris than was $C$. s. septemvittatus.

The UPGMA dendrogram and the minimum length phylogenetic tree shared several important features concerning the relationships between species groups and those within the sexlineatus group. In both, $C$. $t$. marmoratus, representing the tigris species group, is the sister taxon to the sexlineatus species group, and the deppei group is sister to the sexlineatus + tigris clade. Three clades are apparent within the sexlineatus species group. One consists of $C$. sexlineatus and $C$. inornatus, another of $C$. motaguae and $C$. angusticeps, and the third includes $C . s$. septemvittatus, C. s. scalaris, C. gularis, and C. costatus.

Although the UPGMA dendrogram and the minimum length phylogeny are largely concordant, neither is completely robust. Many of the interior nodes in the UPGMA have overlapping standard errors, and in the phylogenetic analyses there were five trees at less than or equal to 137 steps and another 17 at 138 steps, i.e., one and two steps longer than the minimum. All of these trees retained the same arrangement of the species groups and all identified the $C$. sexlineatus $+C$. inornatus and $C$. motaguae + C. angusticeps clades within the sexlineatus group. However, the $C$. s. septemvittatus et al. clade was unstable.

The deppei group clade was present in $100 \%$ of 100 bootstrap replicates and the marmoratus + sexlineatus group clade in $92 \%$. The angusticeps + motaguae and inornatus + sexlineatus clades were present in $80 \%$ and $74 \%$ of bootstraps, respectively. The sexlineatus group, however, was monophyletic in only $62 \%$ of bootstraps. The septemvittatus et al. clade was poorly supported, being present in less than $50 \%$ of replicates.

The fit of the data to various a priori hypotheses was evaluated by constraining phylogenies to form specified monophyletic groups in PAUP (Table 4). Various ways of constructing a monophyletic group including at least one parent from each of the parthenogenetic lineages (excluding $C$. lemniscatus) were tested, with the observed tree lengths varying from 140 to 146 steps, i.e., 4 to 10 steps longer than the shortest tree. The shortest tree consistent with the maternal parents being monophyletic (constraint 3, Table 4) was 146 steps. The shortest tree having the deppei and sexlineatus 
TABLE 3. Distribution of the 71 phylogenetically informative characters among the 13 bisexual species of Cnemidophorus studied. The number for each site refers to its distance $(\mathrm{Kb})$ from the origin of heavy strand replication (Brown and Wright, 1979). Abbreviations of species names, as in Table 2. Abbreviations for restriction enzymes: $\mathrm{a}=A v a \mathrm{I}, \mathrm{b}=$ BamHI, $\mathrm{c}=B c I \mathrm{I}, \mathrm{d}=$ SpeI, $\mathrm{e}=E c o \mathrm{RI}, \mathrm{f}=$ XhoI, $\mathrm{h}=\operatorname{HindIII}, \mathrm{i}=N c \mathrm{I}, \mathrm{l}=$ SalI, $\mathrm{n}=$ NheI, o $=$ NcoI, $\mathrm{p}=P v u \mathrm{II}, \mathrm{v}=E c o \mathrm{RV}, \mathrm{x}=X b a \mathrm{I}$.

\begin{tabular}{|c|c|c|c|c|c|c|c|c|c|c|c|c|c|c|}
\hline Enzyme & Site & LEMD & LEME & DEP & GUT & ANG & MOT & GUL & SEP & SCA & $\cos$ & INO & SEX & MAR \\
\hline c & 0.7 & 0 & 0 & 0 & 0 & 0 & 0 & 0 & 0 & 0 & 0 & 1 & 1 & 0 \\
\hline $\mathrm{n}$ & 0.8 & 0 & 0 & 0 & 0 & 1 & 0 & 1 & 1 & 1 & 0 & 0 & 1 & 1 \\
\hline $\mathrm{n}$ & 0.9 & 0 & 0 & 1 & 1 & 1 & 1 & 1 & 1 & 1 & 1 & 1 & 1 & 1 \\
\hline $\mathrm{h}$ & 1.0 & 0 & 0 & 0 & 0 & 0 & 0 & 1 & 0 & 1 & 0 & 0 & 0 & 0 \\
\hline 0 & 2.0 & 0 & 0 & 0 & 0 & 1 & 1 & 0 & 0 & 0 & 0 & 0 & 0 & 0 \\
\hline $\mathrm{v}$ & 3.3 & 1 & 0 & 0 & 0 & 0 & 0 & 0 & 0 & 0 & 0 & 1 & 1 & 0 \\
\hline a & 3.9 & 0 & 0 & 0 & 0 & 0 & 0 & 1 & 1 & 0 & 0 & 0 & 0 & 0 \\
\hline $\mathrm{v}$ & 3.9 & 0 & 0 & 1 & 1 & 1 & 1 & 0 & 1 & 0 & 1 & 0 & 0 & 1 \\
\hline $\mathrm{p}$ & 4.0 & 0 & 0 & 0 & 0 & 0 & 0 & 0 & 1 & 1 & 1 & 0 & 0 & 1 \\
\hline $\mathrm{n}$ & 4.3 & 0 & 0 & 0 & 0 & 0 & 0 & 1 & 0 & 1 & 0 & 0 & 0 & 0 \\
\hline $\mathrm{e}$ & 4.4 & 0 & 0 & 0 & 0 & 1 & 1 & $\hat{0}$ & 0 & 0 & 0 & 0 & 0 & 0 \\
\hline $\mathrm{c}$ & 4.5 & 0 & 0 & 0 & 0 & 1 & 1 & 1 & 1 & 1 & 1 & 1 & 0 & 1 \\
\hline$x$ & 4.7 & 1 & 0 & 0 & 0 & 0 & 0 & 0 & 0 & 0 & 0 & 0 & 0 & 1 \\
\hline a & 5.0 & 0 & 0 & 0 & 0 & 1 & 1 & 1 & 1 & 1 & 1 & 1 & 1 & 1 \\
\hline o & 5.2 & 1 & 0 & 0 & 0 & 0 & 0 & 1 & 1 & 1 & 0 & 0 & 1 & 0 \\
\hline b & 5.6 & 0 & 0 & 1 & 0 & 1 & 0 & 0 & 0 & 0 & 0 & 1 & 1 & 0 \\
\hline d & 5.9 & 0 & 1 & 1 & 0 & 0 & 0 & 0 & 0 & 0 & 0 & 0 & 0 & 0 \\
\hline 0 & 6.2 & 1 & 1 & 1 & 1 & 0 & 0 & 0 & 0 & 0 & 0 & 0 & 0 & 0 \\
\hline $\mathrm{h}$ & 6.2 & 0 & 0 & 1 & 1 & 0 & 0 & 0 & 0 & 0 & 0 & 0 & 0 & 0 \\
\hline $\mathrm{n}$ & 6.4 & 0 & 0 & 1 & 1 & 0 & 0 & 0 & 0 & 0 & 0 & 0 & 0 & 1 \\
\hline $\mathrm{d}$ & 6.4 & 0 & 0 & 0 & 0 & 1 & 1 & 0 & 0 & 0 & 0 & 0 & 0 & 0 \\
\hline $\mathrm{h}$ & 6.5 & 1 & 1 & 0 & 0 & 1 & 0 & 0 & 0 & 0 & 0 & 0 & 0 & 0 \\
\hline c & 7.0 & 1 & 1 & 0 & 0 & 0 & 0 & 0 & 1 & 1 & 0 & 0 & 0 & 0 \\
\hline p & 7.1 & 0 & 0 & 1 & 1 & 0 & 0 & 0 & 0 & 0 & 0 & 0 & 0 & 0 \\
\hline p & 7.3 & 0 & 0 & 0 & 0 & 1 & 1 & 1 & 1 & 1 & 1 & 1 & 1 & 1 \\
\hline a & 7.5 & 1 & 1 & 0 & 0 & 1 & 0 & 0 & 0 & 0 & 0 & 0 & 0 & 1 \\
\hline $\mathrm{v}$ & 7.6 & 0 & 1 & 0 & 0 & 1 & 0 & 0 & 0 & 1 & 0 & 0 & 0 & 0 \\
\hline p & 7.8 & 0 & 0 & 1 & 1 & 0 & 0 & 0 & 0 & 0 & 0 & 0 & 0 & 0 \\
\hline $\mathrm{h}$ & 8.0 & 0 & 0 & 1 & 1 & 0 & 0 & 0 & 0 & 0 & 0 & 0 & 0 & 0 \\
\hline 1 & 8.4 & 0 & 0 & 1 & 1 & 1 & 1 & 1 & 1 & 1 & 1 & 0 & 0 & 0 \\
\hline $\mathrm{e}$ & 8.5 & 0 & 0 & 0 & 0 & 1 & 1 & 1 & 1 & 1 & 0 & 1 & 1 & 1 \\
\hline c & 8.5 & 1 & 1 & 1 & 1 & 0 & 0 & 0 & 0 & 0 & 0 & 1 & 0 & 0 \\
\hline 1 & 8.9 & 0 & 1 & 0 & 0 & 0 & 0 & 1 & 1 & 1 & 1 & 0 & 1 & 1 \\
\hline $\mathrm{e}$ & 9.0 & 0 & 0 & 0 & 1 & 1 & 1 & 0 & 1 & 1 & 1 & 0 & 0 & 0 \\
\hline $\mathrm{h}$ & 9.1 & 0 & 1 & 0 & 1 & 1 & 0 & 1 & 1 & 1 & 0 & 1 & 1 & 1 \\
\hline c & 9.1 & 0 & 1 & 0 & 0 & 1 & 1 & 1 & 1 & 1 & 1 & 1 & 1 & 0 \\
\hline e & 9.2 & 0 & 0 & 0 & 0 & 1 & 1 & 1 & 1 & 1 & 1 & 0 & 0 & 1 \\
\hline o & 9.3 & 0 & 0 & 0 & 0 & 1 & 1 & 1 & 1 & 1 & 1 & 1 & 0 & 0 \\
\hline $\mathrm{b}$ & 9.5 & 1 & 0 & 0 & 0 & 0 & 0 & 0 & 0 & 0 & 0 & 0 & 0 & 1 \\
\hline 1 & 9.6 & 0 & 0 & 0 & 0 & 0 & 0 & 1 & 1 & 0 & 0 & 0 & 0 & 0 \\
\hline d & 9.8 & 1 & 0 & 0 & 0 & 0 & 0 & 0 & 0 & 0 & 0 & 0 & 0 & 1 \\
\hline $\mathrm{d}$ & 10.0 & 1 & 0 & 0 & 0 & 0 & 0 & 0 & 0 & 0 & 0 & 0 & 0 & 1 \\
\hline $\mathrm{f}$ & 10.1 & 0 & 0 & 1 & 1 & 0 & 0 & 1 & 1 & 1 & 0 & 1 & 1 & 1 \\
\hline h & 10.8 & 0 & 0 & 0 & 0 & 1 & 1 & 1 & 1 & 1 & 1 & 1 & 1 & 1 \\
\hline 1 & 10.7 & 0 & 0 & 0 & 1 & 1 & 1 & 1 & 1 & 1 & 1 & 1 & 1 & 0 \\
\hline $\mathbf{v}$ & 11.1 & 0 & 0 & 1 & 1 & 0 & 0 & 1 & 1 & 1 & 1 & 0 & 1 & 0 \\
\hline 0 & 11.4 & 0 & 0 & 0 & 0 & 1 & 1 & 1 & 1 & 1 & 1 & 1 & 1 & 1 \\
\hline$x$ & 11.6 & 1 & 0 & 0 & 0 & 1 & 1 & 0 & 1 & 0 & 1 & 1 & 1 & 0 \\
\hline $\mathrm{d}$ & 12.1 & 0 & 0 & 1 & 1 & 0 & 0 & 0 & 0 & 0 & 0 & 0 & 0 & 0 \\
\hline $\mathrm{n}$ & 12.3 & 0 & 1 & 0 & 1 & 0 & 0 & 0 & 0 & 0 & 0 & 0 & 0 & 0 \\
\hline c & 12.9 & 0 & 0 & 1 & 1 & 0 & 0 & 0 & 0 & 0 & 0 & 0 & 0 & 0 \\
\hline $\mathrm{p}$ & 13.1 & 0 & 0 & 1 & 1 & 0 & 0 & 0 & 0 & 0 & 0 & 0 & 0 & 0 \\
\hline $\mathrm{c}$ & 13.2 & 0 & 0 & 1 & 1 & 0 & 0 & 1 & 0 & 1 & 1 & 1 & 1 & 0 \\
\hline$x$ & 13.8 & 0 & 0 & 1 & 1 & 0 & 0 & 0 & 0 & 0 & 0 & 0 & 0 & 0 \\
\hline $\mathrm{c}$ & 14.0 & 0 & 0 & 1 & 1 & 0 & 0 & 0 & 0 & 1 & 0 & 0 & 0 & 0 \\
\hline $\mathrm{c}$ & 14.8 & 0 & 0 & 0 & 0 & 0 & 0 & 0 & 0 & 0 & 0 & 1 & 1 & 0 \\
\hline 0 & 15.0 & 0 & 0 & 0 & 0 & 1 & 1 & 1 & 1 & 0 & 1 & 1 & 1 & 0 \\
\hline
\end{tabular}


TABle 3. Continued.

\begin{tabular}{crccccccccccccc}
\hline \hline Enzyme & Site & LEMD & LEME & DEP & GUT & ANG & MOT & GUL & SEP & SCA & COS & INO & SEX & MAR \\
\hline o & 6.2 & 1 & 1 & 0 & 0 & 0 & 0 & 0 & 0 & 0 & 0 & 0 & 0 & 0 \\
x & 8.0 & 1 & 1 & 0 & 0 & 0 & 0 & 0 & 0 & 0 & 0 & 0 & 0 & 0 \\
h & 10.6 & 1 & 1 & 0 & 0 & 0 & 0 & 0 & 0 & 0 & 0 & 0 & 0 & 0 \\
$\mathrm{i}$ & 0.3 & $?$ & $?$ & $?$ & $?$ & $?$ & $?$ & 0 & 0 & 0 & 1 & 1 & 1 & 1 \\
$\mathrm{i}$ & 5.6 & $?$ & $?$ & $?$ & $?$ & $?$ & $?$ & 0 & 1 & 0 & 0 & 0 & 0 & 1 \\
$\mathrm{i}$ & 8.1 & $?$ & $?$ & $?$ & $?$ & $?$ & $?$ & 0 & 0 & 0 & 0 & 1 & 1 & 1 \\
$\mathrm{i}$ & 8.8 & $?$ & $?$ & $?$ & $?$ & $?$ & $?$ & 0 & 1 & 1 & 0 & 0 & 0 & 0 \\
$\mathrm{i}$ & 9.1 & $?$ & $?$ & $?$ & $?$ & $?$ & $?$ & 1 & 1 & 0 & 1 & 1 & 1 & 0 \\
$\mathrm{i}$ & 9.7 & $?$ & $?$ & $?$ & $?$ & $?$ & $?$ & 0 & 1 & 0 & 0 & 0 & 1 & 0 \\
$\mathrm{i}$ & 10.0 & $?$ & $?$ & $?$ & $?$ & $?$ & $?$ & 0 & 0 & 0 & 0 & 0 & 1 & 1 \\
$\mathrm{i}$ & 10.4 & $?$ & $?$ & $?$ & $?$ & $?$ & $?$ & 1 & 1 & 1 & 0 & 1 & 1 & 0 \\
$\mathrm{i}$ & 10.7 & $?$ & $?$ & $?$ & $?$ & $?$ & $?$ & 1 & 1 & 1 & 0 & 0 & 1 & 1 \\
$\mathrm{i}$ & 10.9 & $?$ & $?$ & $?$ & $?$ & $?$ & $?$ & 1 & 1 & 0 & 0 & 1 & 1 & 1 \\
$\mathrm{i}$ & 12.9 & $?$ & $?$ & $?$ & $?$ & $?$ & $?$ & 1 & 1 & 0 & 0 & 0 & 0 & 0 \\
\hline
\end{tabular}

groups as each other's closest relatives (i.e., excluding the tigris group) was 142 steps.

\section{Discussion}

Evaluation of the Phylogeny. - Several attempts have been made to define relationships among the species groups of Cnemidophorus and these have produced inconsistent results. Primarily on the basis of morphology, Burt (1931) proposed that the lemniscatus group represented a basal stock, from which arose the deppei group, and then the other North American species groups. From patterns of variation in chromosomes, Lowe et al. (1970) redefined the composition of the species groups and suggested that the tigris and sexlineatus species groups were sister clades, that the deppei group was the most primitive, and that the lemniscatus group derived from the deppei group. In contrast, UPGMA analysis of allozymes (Dessauer and Cole, 1989) indicated that $C$. deppei is more closely related to members of the sexlineatus group than are species from the tigris group. Alternatively, a cladistic analysis of another set of allozyme data suggested that the tigris and deppei groups were sisters, with the sexlineatus group being the next most closely related (Wright, unpubl. data). The analysis of mtDNA cleavage sites provides strong evidence for a clade consisting of the most northern species groups (sexlineatus $+t i$ gris), as indicated by the chromosomal studies (Lowe et al., 1970), with the more southern deppei group as their closest relatives.
The phylogenetic analysis of the sexlineatus group mtDNAs is incomplete in that mtDNAs from several species have not been examined. However, three clades can be tentatively recognized among the species included: (i) C. sexlineatus $+C$. inornatus, (ii) C. gularis $+C$. s. septemvittatus $+C$. $s$. scalaris $+C$. costatus, and (iii) $C$. angusticeps $+C$. motaguae. The first and second clades are supported by phenetic (Dessauer and Cole, 1989) and cladistic (Wright, unpubl. data) analyses of allozyme data. The close relationship of the members of the $C$. gularis et al. clade is reflected in proposals to include C. s. septemvittatus and C. s. scalaris as subspecies of $C$. gularis (Walker, 1981, 1986, cf Wright et al., 1983). The third conflicts with a morphological analysis (Beargie and McCoy, 1964), which suggested that $C$. angusticeps was most similar to $C$. costatus.

Phylogenetic Constraints on Hybrid Origins.-Among vertebrates, true parthenogenesis occurs only in squamate reptiles where it is found in greater than 30 species (or named forms) from 8 families (Darevsky et al., 1985; Vrijenhoek et al., 1989). This alone indicates strong overall phylogenetic constraint on the evolution of parthenogenesis. Four of these families, Teiidae, Lacertidae, Gymnophthalmidae, and Xantusiidae are thought to represent a monophyletic group (the Lacertoidea), but the others (Chamaeleontidae, Agamidae, Gekkonidae, and Typhylopidae) are distantly related (Estes et al., 1988), indicating that the capacity for hybrid-parthenogenesis must have 


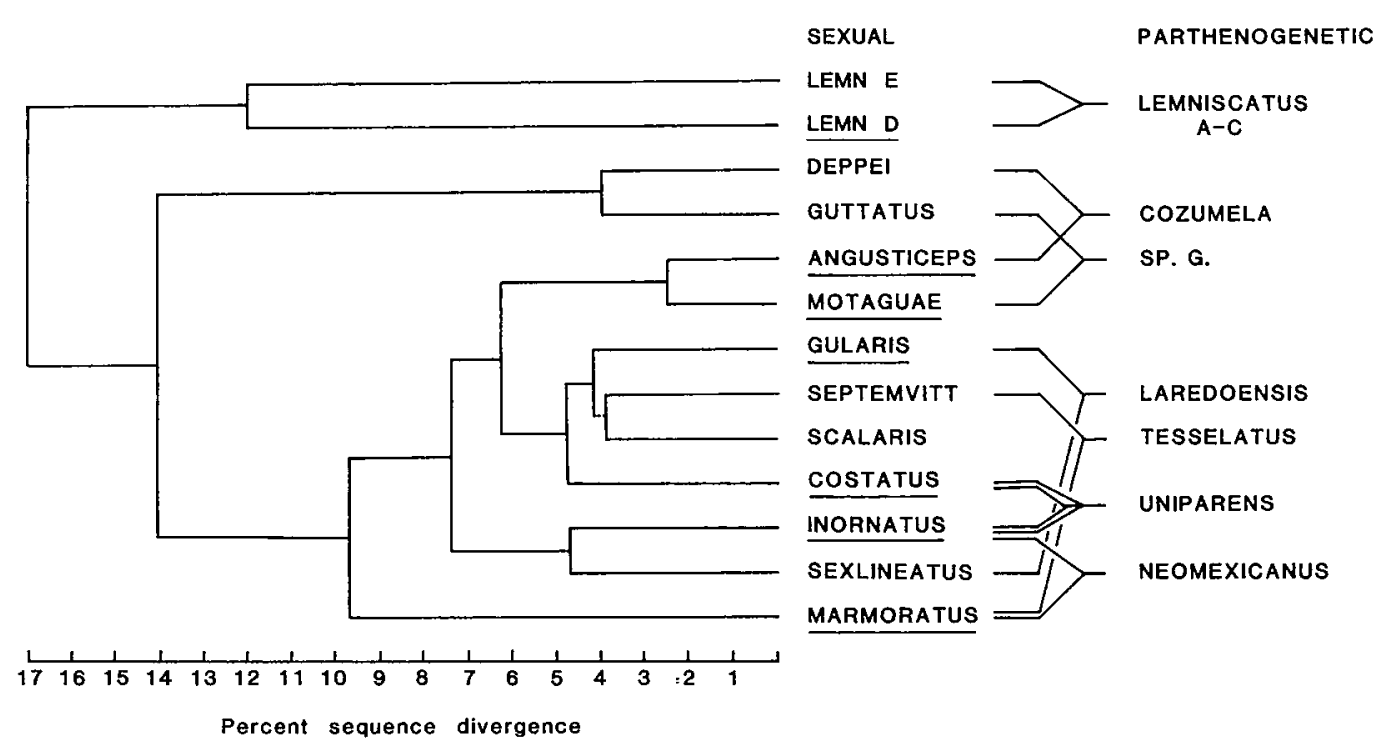

FIG. 1. Dendrogram based on estimates of divergence among mtDNAs from bisexual species of Cnemidophorus that provided the parents of parthenogenetic lineages. The combinations that gave rise to primary (allodiploid) parthenogenetic lineages (see Table 1 for references) are indicated on the right. The maternal parent species are underlined. The single shortest maximum parsimony cladogram was identical except that $C$. gularis was more closely related to $C$. s. scalaris than was $C$. s. septemvittatus. Abbreviations: septemvitt $=C$. $s$. septemvittatus, lemn $=C$. lemniscatus (races $E$ and D). "Uniparens" in this figure encompasses nine morphologically distinct taxa (including $C$. uniparens) and $C$. velox and $C$. exsanguis (see Table 1 for details).

arisen several times within reptiles. However, a large proportion, approximately $50 \%$, of recognized parthenogenetic species are found among Teiid lizards (68\% within the Lacertoidea), suggesting that parthenogenesis has arisen more often in this group than in others (Darevsky et al., 1985). Why are hybrids more likely to be parthenogenetic in some families than in others? For that matter, why in vertebrates is parthenogenesis restricted to reptiles?

To explain this concentration, Darevsky et al. (1985) suggested that there are specific genetic factors that predispose hybrids to parthenogenesis and which arise rarely, probably only once within a given genus. Thus, all parthenogenetic lineages within a given genus should have a least one parent species from the particular clade that has the appropriate genetic factor(s). In the case of Cnemidophorus, they suggested that all parthenogens should have a parent from a single clade within the sexlineatus group.

The above predication is clearly not met. Parthenogenetic $C$. lemniscatus arose by hybridization between bisexual "races" of $C$. lemniscatus (Sites et al., 1990): no sexlinea- tus group species are involved in their ancestry. Hybrid origins involve members of all three clades within the sexlineatus group and no one clade is involved in all events (Fig. 1). Also, there is no phylogenetic concentration of maternal parents. Maternal parent species come from each of the three clades of the sexlineatus group and from the tigris and lemniscatus species groups (Fig. 1). Forcing the maternal parents (excluding C. lemniscatus) to be monophyletic requires an additional 10 steps to explain the data (Table 4).

If there is a specific genetic factor controlling the origin of parthenogenesis by hybridization, then it must either have arisen in a taxon ancestral to all Cnemidophorus (or to the Lacertoidea), or it has arisen on several occasions. Even if such a factor is necessary for hybrid parthenogenesis, it is not sufficient. Not all hybridization events in Cnemidophorus have produced parthenogenetic lineages. Hybridization has been reported between $C$. gularis, C. s. septemvittatus, and C. s. scalaris (Walker, 1981, 1986) and between C. t. marmoratus and C. t. gracilis (Dessauer et al., 1962), yet no 
TABLE 4. Tree lengths and statistics (C.I. = consistency index; R.I. = retention index) for different constraints on monophyletic groups that must be present. Notation for monophyletic groups follows Swofford (1990) and uses the abbreviations for species names defined in Table 2.

\begin{tabular}{lcccc}
\hline \hline Monophyletic group in constraint & Length & No. trees & C.I. & R.l. \\
\hline 1. ((ANG, MOT, SEP, GUL, COS, INO)) & 143 & 3 & 0.50 & 0.55 \\
2. ((ANG, MOT, SEP, SEX, COS, INO)) & 140 & 3 & 0.51 & 0.57 \\
3. ((ANG, MOT, MAR, GUL, COS, INO)) & 146 & 1 & 0.49 & 0.53 \\
4. ((ANG, MOT, SEP, GUL, COS, MAR)) & 143 & 4 & 0.50 & 0.55 \\
\hline
\end{tabular}

parthenogenetic lineages have been formed in these cases. While these phylogenetic patterns cannot rigorously exclude a single gene effect, they suggest that complex genetic models might be more appropriate.

One suggestion is that hybrid parthenogenesis results from a more general genetic perturbation, involving numerous genes of small effect that regulate meiosis and other aspects of development (White, 1978). The balance hypothesis (Moritz et al., 1989a; see also Vrijenhoek, 1989) suggests that parental species must be divergent enough to disrupt the genetic control of meiosis in hybrids, but not so different as to severely reduce the viability or fecundity of hybrids. This predicts some minimal level of divergence between parental species below which hybridization does not result in stable parthenogenesis.

The results of the phylogenetic analysis of Cnemidophorus are consistent with the balance hypothesis. The only consistent feature of the combinations of bisexual species that have yielded parthenogens by hybridization is that they are distantly related or genetically divergent (see also Dessauer and Cole, 1989). This is obvious for the lineages descended from interspecies-group hybrids, e.g., C. tesselatus, $C$. neomexicanus, and the cozumela complex (Fig. 1). It is also the case for hybrid origins where both parental species come from the sexlineatus group: these always involve species from different clades (e.g., C. laredoensis, C. uniparens, etc., Fig. 1). Even the parents of parthenogenetic $C$. lemniscatus, included under the same name, are strongly differentiated for both mtDNA (Fig. 1; Vyas et al., 1990) and allozymes (Sites et al., 1990). In contrast, there is no evidence that the hybrids formed between more closely related taxa (e.g., $C$. gularis, C. $s$. septemvittatus, and C. s. scalaris; C.t. marmoratus, and C.t. gracilis) are parthenogenetic.

\section{ACKNOWLEDGMENTS}

We thank V. Singh, K. Blakely, L. D. Densmore, and D. Vyas for laboratory assistance, I. Darevsky, S. Edwards, and C. Schneider for comments on the manuscript, and L. Pryor for illustration. This work was supported by grants from the National Science Foundation and the National Institutes of Health.

\section{LITERATURe Cited}

BEARGIE, K., AND C. J. MCCOY, JR. 1964. Variation and relationships of the Teiid lizard Cnemidophorus angusticeps. Copeia 1964:561-570.

BeLl, G. 1982. The Masterpiece of Nature. Croom Helm, Canberra, Australia.

Brown, W. M. 1980. Polymorphism in mitochondrial DNA of humans as revealed by restriction endonuclease analysis. Proc. Natl. Acad. Sci. 77: 3605-3609.

Brown, W. M., AND J. W. Wright. 1979. Mitochondrial DNA analyses and the origin and relative age of parthenogenetic lizards (genus Cnemidophorus). Science 203:1247-1249.

BURT, C. E. 1931. A study of the Teiid lizards of the genus Cnemidophorus with special reference to their phylogenetic relationships. Bull. Smithson. Inst. 154: $1-280$.

DAREVSKY, I. S., L. A. KUPRIYANOVA, AND T. UZZEIL. 1985. Parthenogenesis in reptiles, pp. 412-526. In C. Gans and F. Billett (eds.), Biology of the Reptilia, vol. 15B, Wiley, N.Y., USA.

Densmore, L. D., C. Morutz, J. W. Wrught, and W. M. Brown. 1989a. Mitochondrial DNA and the origin and relative age of parthenogenetic Cnemidophorus (Teiidae: Reptilia): Nine sexlineatus group parthenoforms. Evolution 43:969-983.

DeNSMORE, L. D., J. W. WRight, AND W. M. BRown. 1985. Length variation and heteroplasmy are frequent in mitochondrial DNA from parthenogenetic and bisexual lizards (genus Cnemidophorus). Genetics 110:689-707.

- 1989b. Mitochondrial DNA and the origin and relative age of parthenogenetic Cnemidophorus: $C$. neomexicanus and the tesselatus complex. Evolution 43:943-957. 
Dessauer, H. C., And C. J. Cole. 1989. Diversity within and between nominal forms of unisexual lizards, pp. 49-71. In R. M. Dawley and J. P. Bogart (eds.), Evolution and Ecology of Unisexual Vertebrates. New York State Museum, Albany, NY, USA.

Dessauer, H. C., W. Fox, AND F. H. Pough. 1962. Starch gel electrophoresis of transferrins, esterases, and other plasma proteins between two subspecies of whiptail lizard (genus Cnemidophorus). Copeia 1962:767-774.

Dowling, T. E., C. Moritz, AND J. PAlmer. 1990. Nucleic acids II. Restriction site analysis, pp. 250319. In D. M. Hillis and C. Moritz (eds.), Molecular Systematics. Sinauer Assoc., Sunderland, MA, USA.

Estes, R., K. DE Queiroz, AND J. Gauthier. 1988. Phylogenetic relationships within Squamata, pp. 119-281. In R. Estes and G. Pregill (eds.), Phylogenetic Relationships of Lizard Families. Stanford Univ. Press, Palo Alto, CA, USA.

GolubovskayA, I. N. 1979. Genetic control of meiosis. Int. Rev. Cytol. 58:247-290.

INNES, D. J., AND P. N. D. Hebert. 1988. The origin and genetic basis of obligate parthenogenesis in Daphnia pulex. Evolution 42:1024-1035.

LAMB, R. Y., AND R. B. WILlEY. 1979. Are parthenogenetic and related bisexual insects equal in fertility? Evolution 33:774-775.

Lowe, C. H., J. W. Wright, C. J. Cole, AND R. L. BEZY. 1970. Chromosomes and evolution of the species groups of Cnemidophorus (Reptilia: Teiidae). Syst. Zool. 19:128-141.

Michod, R. E., AND B. R. Levin. 1988. The Evolution of Sex. Sinauer, Sunderland, MA, USA.

Moritz, C., AND W. M. Brown. 1987. Tandem duplications in animal mitochondrial DNAs: Variation in incidence and gene content among lizards. Proc. Natl. Acad. Sci. 84:7183-7187.

MortTz, C., W. M. Brown, L. D. Densmore, J. W. Wright, D. Vyas, S. DONNellan, M. Adams, and P. R. BAVERSTOCK. 1989a. Genetic diversity and the dynamics of hybrid parthenogenesis in Cnemidophorus (Teiidae) and Heteronotia (Gekkonidae), pp. 87-112. In R. M. Dawley and J. P. Bogart (eds.), Evolution and Ecology of Unisexual Vertebrates. New York State Museum Press, Albany, NY, USA.

Moritz, C., J. W. Wright, AND W. M. Brown. $1989 b$. Mitochondrial DNA analyses and the origin and relative age of parthenogenetic Cnemidophorus (Teiidae: Reptilia): $C$. velox and $C$. exsanguis. Evolution 43:958-968.

NEI, M. 1972. Genetic distance between populations. Am. Nat. 106:283-292.

Nei, M., J. C. StePhens, AND N. SAItou. 1985. Methods for computing the standard errors of branching points in an evolutionary tree and their application to molecular data from humans and apes. Mol. Biol. Evol. 2:66-85.

Nei, M., AND F. TAJima. 1983. Maximum likelihood estimation of the number of nucleotide substitu- tions from restriction site data. Genetics 105:207217.

Sites, J. W., JR., D. M. Peccinini-Seale, C. Moritz, J. W. Wright, AND W. M. Brown. 1990. The evolutionary history of parthenogenetic Cnemidophorus lemniscatus (Sauria: Teiidae). I. Evidence for hybrid origin. Evolution 44:906-921.

Suomalainen, E., A. Saura, and J. Lokki. 1987. Cytology and Evolution in Parthenogenesis. CRC Press, Boca Raton, FL, USA.

SwoFford, D. L. 1990. PAUP Version 3.0, Illinois Natural History Survey.

Templeton, A. R. 1982. The prophecies of parthenogenesis, pp. 75-101. In H. Dingle and J. P. Hegmann (eds.), Evolution and Genetics of Life Histories. Springer-Verlag, N.Y., USA.

VRIJENHOEK, R.C. 1989. Genetic and ecological constraints on the origins and establishment of unisexual vertebrates, pp. 24-31. In R. M. Dawley and J. P. Bogart (eds.), Evolution and Ecology of Unisexual Vertebrates. New York State Museum Press, Albany, NY, USA.

VRiJenhoek, R. C., R. M. DAwley, C. J. Cole, AND J. P. BOGART. 1989. A list of the known unisexual vertebrates, pp. 19-23. In R. M. Dawley and J. P. Bogart (eds.), Evolution and Ecology of Unisexual Vertebrates. New York State Museum Press, Albany, NY, USA.

Vyas, D., C. Moritz, D. Peccinini-Seale, J. W. Wright, AND W. M. BRown. 1990. The evolutionary history of parthenogenetic Cnemidophorus lemniscatus (Sauria: Teiidae). II. Maternal origin and age inferred from mitochondrial DNA analysis. Evolution 44:922-932.

WALKER, J. M. 1981. Systematics of Cnemidophorus gularis. I. Reallocation of populations currently allocated to Cnemidophorus gularis and Cnemidophorus scalaris in Coahuila, Mexico. Copeia 1981: 826-849.

- 1986. The taxonomy of parthenogenetic species of hybrid origin: Cloned hybrid populations of Cnemidophorus (Sauria: Teiidae). Syst. Zool. 35: 427-440.

Wetherington, J. D., K. E. Kotora, AND R. C. VRIJENHOEK. 1987. A test of the spontaneous heterosis hypothesis for unisexual vertebrates. Evolution 41:721-731.

White, M. J. D. 1978. Modes of Speciation. W. H. Freeman, San Francisco, CA, USA.

Williams, G. C. 1975. Sex and Evolution. Princeton Univ. Press, Princeton, NJ, USA.

Wright, J. W. 1978. Parthenogenetic lizards. Science 201:1152-1154.

Wright, J., C. Spolsky, AND W. M. Brown. 1983. The origin of the parthenogenetic lizard Cnemidophorus laredoensis inferred from mitochondrial DNA analysis. Herpetologica 39:410-416.

Corresponding Editor: J. J. Bull 